\title{
Claiming the Term "Liberal" in Academic Religious Discourse
}

\author{
Sofia Betancourt ${ }^{1}$, Dan McKanan ${ }^{2, *}$, Tisa Wenger ${ }^{3}$ and Sheri Prud'homme ${ }^{4}$ \\ 1 Theology and Ethics, Starr King School for the Ministry, Oakland, CA 94613, USA; sbetancourt@sksm.edu \\ Harvard Divinity School, Harvard University, Cambridge, MA 02138, USA \\ 3 Yale Divinity School, Yale University, New Haven, CT 06511, USA; tisa.wenger@yale.edu \\ 4 Religion and Education, Starr King School for the Ministry, Oakland, CA 94613, USA; \\ sprudhomme@sksm.edu \\ * Correspondence: dmckanan@hds.harvard.edu
}

Received: 20 May 2020; Accepted: 11 June 2020; Published: 24 June 2020

check for updates

\section{Introduction}

\section{Sheri Prud'homme}

The three papers which follow were originally presented at the triennial Unitarian Universalist Convocation in 2016, sponsored by the Unitarian Universalist History and Heritage Society and Collegium, an Association for Liberal Religious Studies. This panel sought to push our thinking as religious liberals about the very term "liberal" as it is employed, or not, by Unitarian Universalists in academic discourse in religious studies, theology, and ethics. The conversation remains as relevant today as it was nearly three years ago.

In academic religious discourse, "liberal" is a contested term. Many scholars with roots in Unitarian Universalism do not claim the term "liberal" in their scholarly work. The liberal theologies group of the American Academy of Religious is a relatively small group that has at times in recent years struggled to receive enough papers to assemble a vital session. The Journal of Liberal Religion has not been published since 2009. The two Unitarian Universalist seminaries do not lead with the term in their promotional materials. Meadville Lombard Theological School has retained the word "liberal" in its mission, but it is several layers behind the first page of its website. Starr King School for the Ministry does not use the word in its mission, opting instead for the phrase "progressive religious leadership", but "liberal" appears in some course descriptions. Gary Dorrien notes in a 2013 Religion Dispatches article that "liberal Protestant" is not a term used at Union Theological Seminary nor most other theological schools once known as bastions of liberal Protestant theology. To do so, he writes, "would smack of provincialism and the cultural presumptions of the mainline from a bygone time. And it would exclude our faculty and students that lack any connection to liberal Protestantism". ${ }^{1}$

However, Unitarian Universalism continues to be a religious movement that utilizes the term "liberal" in a positive light, in spite of the complexity of the term. The professional organization for Unitarian Universalist religious educators bears the name Liberal Religious Educators' Association. Collegium calls itself "an association for liberal religious studies". Paul Rasor, an ordained Unitarian Universalist minister and scholar, subtitled his latest book (Rasor 2013) Reclaiming Prophetic Witness with the phrase "Liberal Religion in the Public Square". Unitarian Universalism is not entirely alone in claiming liberal religion. On 23 July 2013, an article “A Religious Legacy, With Its Leftward Tilt,

1 Gary Dorrien, “The Protestant Mainline Makes a (Literary) Comeback”. Religion Dispatches (5 August 2013): http: //religiondispatches.org/the-protestant-mainline-makes-a-literary-comeback/ (accessed on 6 May 2019). 
Is Reconsidered" by Jennifer Schuessler in the New York Times noted a surge of new writing on liberal Protestantism. Rabbi Eric H. Yoffee, President Emeritus of the Union for Reformed Judaism wrote a 21 November 2016 article in the Huffington Post entitled "Now is Liberal Religion's Moment". A number of scholars are writing on liberal Islam including Mustafa Akyol's 2011 book Islam Without Extremes (W. W. Norton \& Company), which is an argument for "Muslim liberalism".

Given critiques from neo-orthodoxy on the one hand and from liberationists on the other, what are some current positions of Unitarian Universalist scholars on claiming the term liberal in academic discourse? How is the term currently defined? For scholars of what has traditionally been known as liberal religion, what work is waiting to be done to complicate, reclaim, or reject the term?

Three papers follow, and each adds important elements to the conversation. Sofia Betancourt, Associate Professor of Unitarian Universalist Theologies and Ethics at Starr King School for the Ministry, urges us to prioritize "liberation" in pairing it with "liberal", centering praxis along with the voices and experiences that liberal religion has historically silenced or pushed to the margins so that we can dismantle white supremacy at the foundations of our faith. She argues that liberation demands relational, accountable work informed by solidarity, moving beyond predominantly white cultural heritages and norms, to "resacralize what has been desecrated through dominance and oppression" and learn from those "whose collective survival and promised liberation can truly remake the world".

Dan McKanan, Ralph Waldo Emerson Unitarian Universalist Association Senior Lecturer in Divinity at Harvard Divinity School, argues that the tools of liberalism-individual autonomy, free-thinking, and self-criticism-remain relevant resources in the struggle against oppression's myriad forms, including neoliberalism's glorification of the free market. At the same time, he cautions against liberalism's tendency to be biased against all tradition and everything rooted in the past. He concludes he is open to the possibility that the term "liberal" itself excludes others and suggests we may need to "find new words for the perennial quest for freedom".

Tisa Wenger, Associate Professor of American Religious History, Divinity School and American Studies at Yale University begins with her historical scholarship that reveals the complicity of liberals in the United States with racism, settler colonialism, and imperialism as well as illuminating the liberal foundations of movements for social justice, human flourishing, and ecological sustainability. She notes that religious liberalism's concern for an individual quest for truth and meaning and the freedom of conscience can easily foster privilege, complacency, hierarchies, and exclusions without attending to inequities, including neoliberalism's extending of liberal ideals to the free market. She calls for “Unitarian Universalists to identify themselves not with 'religious liberalism' or 'liberal religion' but as a relational community of flourishing and liberation for all".

In the continual unfolding of Unitarian Universalism, it is my hope that these papers will be fruitful conversation partners for scholars and ministers alike as we make our way forward into the coming decades.

\section{Toward a Liberal and Liberating Faith}

\section{Sofia Betancourt}

Since the time of our panel conversation at the Unitarian Universalist Convocation in 2016, I have witnessed an increasing engagement with the utility of the term "liberal" in our current context. In just three years, Unitarian Universalist theologians and religious leaders of all types have been in conversation about the potential shift in our movement to embrace a liberal theology with liberation at its core. This is a complex intention given certain aspects of our history and our demographics, even as those continue to shift and diversify with time. However, there is no question for me that our relevance as a tradition that centers its religious expression on shared ethics and the promotion of justice depends on the renewal of our tradition as a liberal and liberating faith. Liberation must serve as our measure of integrity in the long overdue work to dismantle the influences and legacies of white supremacy and the wide range of dehumanizing injustices in our midst. 
Three years ago, when our colleague first reached out to our group to propose this discussion, I had not invested much energy into thinking about my position on the term "liberal". I had been in several conversations about Unitarian Universalist scholars and why we might or might not claim our Unitarian Universalist identities within the academy. Using the term "liberal" seemed a forgone conclusion after making the decision to claim a denominational label. Recognizing that we understand an uncritical lack of reflection as a moral failing in our movement, I acknowledged at the outset that I do not use the term "liberal" in my research or writing unless in very specific situations such as giving a paper within the liberal theologies group at the American Academy of Religion. Instead, I fall into the camp of working toward "liberation" and on and with a liberatory theoethics. Complicating this practice is my periodic work in the parish, where I regularly preach about our liberal and liberating faith.

There is something vital in the interplay of these two terms- "liberal" and "liberation". My research in Womanist and Latina Feminist theoethics owes a great deal to liberation theologies-both the black liberation scholarship founded by James Cone and the Latin American liberation theologies established by Gustavo Gutierrez. These two co-evolving lines of thought require of me something that I am regularly missing within liberal theologies, and that is praxis. Praxis as a secular term challenges us to engage the world through a combination of reflection and action. I am particularly convicted by the work of Brazilian educator and philosopher Paulo Freire who in his Pedagogy of the Oppressed places praxis within the deeper framework of a liberatory communal education process that pushes societal evolution, when he coins the term conscientization. Simply put, conscientization is "the process of developing a critical awareness of one's social reality through reflection and action". ${ }^{2}$ Freire is speaking to a condition that I often find problematic within Western philosophy and theology, and that is the search for an overarching, definitive, singular Universal truth. By this, I do not mean a final truth or a moment when revelation can be sealed at long last and we can all find other things to do with our time. However, tensions in our work between the particularist approach that seeks to return long silenced voices that have been pushed to the margins back to the center of the theoethical task and the desire for a singular universal truth that can be applied to all inquiries remain central to this question.

The legacies of white supremacy and all forms of domination are easily hidden within the call for a universally applicable truth. I situate myself, and my scholarship, with Latina feminist and Womanist scholars who argue for holding multiple truths as equally important and shaping of our work. Freire offers critical resources for this approach because he is driven by the creation of methods of learning that return agency to marginalized communities by interrupting the imposed norms of a dominant culture and the kind of internalized oppression that prevents real understanding of the situations in which we find ourselves, thus thwarting revolutionary change. He himself writes "reflection upon situationality is reflection about the very condition of existence. [It is] critical thinking by means of which people discover each other to be 'in a situation.' Only as this situation ceases to present itself as a dense, enveloping reality ... and they can come to perceive it as an objective-problematic situation-only then can commitment exist. Humankind emerge from their submersion and acquire the ability to intervene in reality as it is unveiled. Intervention in reality-historical awareness itself-thus represents a step forward from emergence, and results from the [conscientization] of the situation. [Conscientization] is the deepening of the attitude of awareness characteristic of all emergence" ${ }^{3}$

I want to honor the work of the Rev. Dr. Katie G. Cannon, who first taught conscientization as a vital ingredient in Womanist methodologies. I also want to acknowledge that there is room for action within our own liberal religious discourse as we have understood it over time. James Luther Adams regularly offered us four important aspects of liberal thought, and one of them is the "moral obligation

2 “Concepts Used by Paolo Freire", Freire Institute, accessed 3 May 2019, https://www.freire.org/paulo-freire/concepts-usedby-paulo-freire/.

3 Paulo Freire, Pedagogy of the Oppressed 30th Anniversary Edition, trans. Myra Bergman Ramos (New York, Continuum, 2001), p. 109. 
to direct one's efforts toward the establishment of democratic community". ${ }^{4}$ What is missing for me is the prior step of working together in community to unmask for ourselves that "dense, enveloping reality" that Freire writes about that keeps us unaware of, or resigned to, the dehumanizing realities of our day-to-day living. Consequently, there is still utility in the term "liberal" but not on its own. "Liberal" without "liberation" reads too much of dominant cultural assumptions that liberation is implied while only rarely doing the relational, accountable work driven by an informed solidarity to better understand what is needed. One practical expression of the ramifications of relying solely on liberal concepts to express our highest values in life is the reality that most academic discussions of liberal theology are held within groups of scholars who are entirely white. I simply expect to be the only scholar of color in the room when liberal thought is at the center of the theological task. As we work to dismantle the white supremacy within our midst and at the foundations of our faith, we must prioritize the wisdom of liberation that comes from minds and lived experiences beyond our predominantly white cultural heritages and norms. If we are to be saved together, and resacralize what has been desecrated through dominance and oppression, we must relinquish our control over the meaning of faithful living and center a new learning on those whose collective survival and promised liberation can truly remake the world.

\section{Claiming the Term "Liberal"}

\section{Dan McKanan}

Liberalism is a tradition of rebellion against inherited authority that seeks to free individuals and communities from bondage of the body, mind, and spirit. The tools it uses to liberate people include individual autonomy, free thinking, and self-criticism. It is important to recognize these as tools, not as the exclusive ends of liberalism. Some people have suggested that liberalism cares more about freedom of the mind than of the body, but I do not think that is quite true. Eighteenth- and nineteenth-century liberals were often deeply committed to freeing the bodies of serfs and slaves from coerced labor, and the bodies of women from sexual exploitation. It is true, nevertheless, that liberals have generally assumed that the freedom of the mind is an indispensable tool in struggles to free bodies.

Liberalism remains relevant as long as people are oppressed by forms of traditional authority, including patriarchy, monarchy, dogmatic religious authority, and caste and racial hierarchies. I count myself a liberal in part because these forms of authority are still very much with us.

On the other hand, much of the injustice that people face today can be laid at the feet of liberalism itself. Two centuries ago, Adam Smith promoted capitalism as a liberating alternative to the self-aggrandizing and warlike practices of monarchical governments. The end result has been a network of exploitative corporations that wreak havoc on both human lives and the environment. However, if liberalism is part of the problem here, it can also be part of the solution. At least since the Social Gospel and Progressive movements of a century ago, many liberals have recognized corporate capitalism as a distorted form of liberalism that puts the rights of investors ahead of the right of workers to feed their families and shape the circumstances of their labor. For these liberals, self-criticism was the paramount liberal value, and it allowed them to remain faithfully liberal even as they repudiated earlier liberal commitments to a free market economy.

Liberalism thus remains a relevant resource for the struggle against two contrasting but intertwined evils that beset the world today. To the extent that the world is threatened by white supremacy, heteronomativity, patriarchy, and authoritarian forms of government, liberalism's defining opposition to inherited authority is directly relevant. To the extent that the greater danger is a "neoliberalism" that treats market freedom as the paramount value, self-critical liberals offer an alternative vision in which the freedom of people carries more weight than the freedom of money.

4 James Luther Adams, "Why Liberal", 6. 
To be sure, liberalism is not the only tradition that offers resources for these two struggles, but it does offer some unique resources. Because capitalism itself is a fruit of liberalism, liberal anti-capitalism can help activists recover some of the genuine values, such as creativity, that are carried by capitalism in a distorted form. Liberalism also offers important safeguards against the authoritarian tendencies of some of the other movements that resist neoliberalism, among them orthodox Marxism and religious fundamentalism.

At the same time, liberalism carries some significant dangers of its own. In criticizing traditional forms of authority, it can spread a bias against tradition itself and against everything rooted in the past. This is problematic whenever and wherever it happens, because sometimes, the past has exactly the wisdom needed to resist the evils of the present. It is, moreover, especially problematic in the context of empire. Metropolitan liberals should not direct their critique willy-nilly against the traditions of subaltern communities.

Liberalism also tends to treat freedom as the supreme or only value, but freedom is of little use if it does not free us to pursue other values, such as connection, cooperation, beauty, and insight. Such values, of course, are often carried by religious and cultural traditions. The current environmental crisis is an especially pointed reminder of the importance of traditional or "conserving" values.

For this reason, I ultimately am more comfortable with "liberal" as an adjective than "liberalism" as a noun. I can have a liberal approach to the traditions I value, but if liberalism is the only tradition I claim then there is much that I will have to forsake.

This creates a dilemma for Unitarian Universalists (UUs), most of whom have forsaken "liberal Christianity" for "religious liberalism". I do not want to turn back the clock on this, but I do think that UU congregations could be places for thoughtful conversations about what it means to be liberal in our connection to our various traditions. For UU Christians, this is fairly obvious; for UU pagans and Buddhists, being a liberal pagan or a liberal Buddhist might mean resisting patriarchal strands of those traditions or tendencies to invest excessive power in individual teachers.

For me, one relevant religious tradition is, in fact, Christianity. I call myself a liberal Christian because I think that the legacy of Jesus Christ alerts us to the divine potential in every person. The liberal approach empowers me to apply Jesus' radical teaching about God's love for the poor to other oppressed groups about whom Jesus did not speak so directly, among them sexual and gender minorities, persons with disabilities, victims of racialized oppression, and many more.

But I also think a lot about what it means to be "liberal leftist" or "liberal socialist". I am deeply committed to the socialist quest for a thoroughgoing alternative to capitalism, one in which all people exercise direct democratic control of the places where they work. However, my liberal love of freedom makes me skeptical of state power as the primary means for building cooperative economics. I am also wary of the subordination of means to ends in Marxist theory and, more especially, Leninist, Stalinist, and Maoist practice. John Haynes Holmes, Egbert Ethelred Brown, Homer Jack, Bayard Rustin, A. J. Muste, and many others provide compelling models for how to support socialism as a liberal.

Insofar as the left is also a tradition that privileges freedom over other values, calling myself a "liberal leftist" does not quite address the problem of liberal bias against the past. To fully overcome this problem, I must be a "liberal ecologist" as a well as a liberal leftist and a liberal Christian. The ecological tradition is committed to the preservation of ecosystems, biodiversity, and local interconnections between human and biotic communities. Much more than liberalism or the left, ecology has often garnered strong support from people who are also devoted to religious and cultural traditions. It does not, typically, identify freedom as a core value, and certain forms of ecology are explicitly and emphatically illiberal. Among those I would count strands of deep ecology that treat humanity as intrinsically threatening to life forms, approaches to wilderness preservation that justify the removal of indigenous communities, and models of sustainability that assume that ecological change is always a bad thing. However, there is no inherent conflict between human freedom and ecological balance: just as people can and should freely choose to cherish certain cultural traditions, 
so humans and other life forms can make free choices that keep us in balance with one another. Indeed, by warding against dogmatic or monocultural responses to environmental problems, the liberal approach can play a big role in helping Earth regain its balance.

For all these reasons, I will seek to remain faithful to the best of the values that have historically been called liberal. At the same time, my commitment to self-criticism reminds me that what words mean to me are not always the same as what they mean to others. To the extent that many people feel excluded by the word "liberal", it may be that the most liberal course of action is to find new words for the perennial quest for freedom.

\section{The Problem with Liberalism}

\section{Tisa Wenger}

I have never wanted to identify myself as a "liberal" or to embrace the moniker of "liberal religion". This is not a result of the conservative attacks on liberalism-that would be a reason to embrace it—but of liberalism's own limitations, contradictions, and exclusions. Instead of working out an alternative, though, my tendency has always been to hide behind the identity of an historian. I am more comfortable with (and better at) the task of deconstructing and historicizing such terms than the constructive work of proposing alternatives. However, we know that historical questions and terms of analysis are shaped as much as any other kind of intellectual inquiry by the historian's social identities and normative commitments. Thus, I am grateful if a bit nervous to be forced by this forum to face up to the question.

Here is the problem as I see it. My own scholarship shows the historical complicity of American liberals and liberalism in racism, settler colonialism, and imperialism. When I see liberalism's continued blind spots and exclusions today, I am left asking whether the liberal tradition has anything left worth salvaging. However, I recognize that my own commitments to social justice, human flourishing, and ecological sustainability-along with the Unitarian Universalist tradition-all have liberal foundations. What positive legacies and trajectories might be lost with the rejection of liberalism? What alternative grounding can we claim for the values we want to live by and to foster?

Liberalism is a shape-shifting concept that has meant many different things over time. First came the classical liberalism of the eighteenth and nineteenth centuries. This liberalism focused above all on the rights and freedoms of the individual subject. It inspired the challenges to theological orthodoxies that still define religious liberalism, and whether or not they identify as "religious liberals", most Unitarian Universalists today remain committed to its basic ideals. However, it was no accident that the early liberal philosophers invariably spoke of the individual whose rights they championed as white and male. As historians of race and gender have amply demonstrated, these thinkers largely assumed (and sometimes advocated) the subjugation of the women and slaves whose service supported the patriarchal household and in so doing enabled the fiction of white male autonomy (Patterson 1991; Hartman 1997). The history of religious liberalism cannot be separated from this side of liberalism's legacy.

Liberal ideals also served as powerful rationales for settler colonialism and empire. Freedom and rationality were said to be universal but fully developed only among the supposedly more "civilized" races. Through this logic, liberal imperialists could readily claim the responsibility to bestow (or impose) them upon the so-called "primitives" whose capacities, so it seemed, perpetually lagged behind. Some of the leading liberal philosophers of the eighteenth and nineteenth centuries, men like John Locke and John Stuart Mill, served simultaneously as colonial administrators and theorists of empire. They defended imperialism as justifiable, even laudable and benevolent, because it provided a way to bring the values and virtues of freedom and civilization to the racialized subjects of colonial rule. Contemporary exercises of imperial power are rationalized in much the same way, even when the reigning political philosophies do not go by the name liberal (Mehta 1999; Lowe 2015). 
When embraced by relatively privileged people—as they so often are-the liberal emphases on freedom of choice and freedom of conscience can shape a live-and-let-live culture that makes it difficult to name and combat injustice. In the decades before the Civil War, many Unitarians and Universalists, like many other Protestants at the time, refused to challenge slavery on the grounds that conscientious Christians disagreed on the question of slaveholding and that the state had no right to dictate in matters of conscience. Although abolitionists pointed out that this formulation ignored the slaves' rights to the same freedoms, many religious liberals opposed abolitionism for decades, in part on religious freedom grounds (Jordan 2012; Wenger 2017).

In the same way, white liberals were all too often complacent in the face of racial segregation. Although many black and white Unitarian Universalists were active in the civil rights movement-a legacy that contemporary Unitarian Universalists rightly celebrate-white liberals more often hesitated to support its radical urgencies. Religious liberalism can operate in similar ways today, as Unitarian Universalists committed to the individual quest for truth and meaning all too easily end up fostering a culture of privilege and complacency, and can too easily celebrate an atomized, individualized freedom that fails to acknowledge the inequities of power on the ground.

This is not to say that all liberals have been complacent imperialists or that liberalism has offered no resources for resistance. Far from it. Many liberals-and others who may not claim that label but have gained inspiration from liberal ideals-have applied the principles of freedom and equality in radical ways to challenge the imperial hierarchies of gender, sexuality, race, and nation. Global movements for women's rights and against slavery and imperialism have articulated their protests at least in part in the language of liberalism. Most of those who claim liberal identities today aim to defend these legacies and commitments (McKanan 2011).

In much of what passes for public discourse in the United States today, liberalism is attacked not because of its complicity with racism and imperialism but on very different grounds. Some oppose liberalism as a threat to religious traditions and the social hierarchies they so often sanctify. Others condemn it for empowering big government at the expense of individual and corporate "freedoms". The liberalisms these critics fear are the mid-twentieth-century programs of the New Deal and the Great Society, which sought to wield the government's power to eliminate poverty and create equal justice for all. President Franklin Delano Roosevelt's Four Freedoms, including the "freedom from want" and the "freedom from fear", recognized that basic human needs had to be met before any "freedom" could have much meaning. In practice, though, these programs too were focused and limited in ways that maintained the racial hierarchies and exclusions of American society (Engel 2015).

The individual and corporate freedoms so loudly proclaimed against these mid-century liberalisms are themselves rooted in the neoliberalism that has shaped successive U.S. administrations over the past four decades. Neoliberalism identifies free markets as the basic building blocks of human freedom and redefines all of life in transactional terms. It celebrates economists' analysis of human nature through the language of homo economicus and indeed works to reshape human subjectivity through the lens of the free market. In both theory and practice, it takes the liberal ideals of individuality and freedom to their logical and most harmful extremes. Like the individual liberties of an earlier age, neoliberal freedoms work best for those who are already wealthy and privileged. For anyone who cares about social justice, about the flourishing of diverse human and ecological communities, and indeed about the future of the planet itself, this may be liberalism's most dangerous spawn (Comaroff and Comaroff 2001; Brown 2015).

A fuller accounting of the relationships and distinctions between religious, philosophical, and political liberalisms would need to encompass not only a history of ideas but also the networks, practices, and material commitments of those who have claimed these identities. Such a history would place people of color as active agents within liberal religious movements, honor the emancipatory impulses at the heart of these movements, and wrestle with the hierarchies and exclusions (racial and otherwise) that the overlapping forms of liberalism have so often perpetrated. 
All this history may help us understand why "liberalism" is such an embattled term, one that many Unitarian Universalists and liberal Protestants today are not particularly eager to claim. It may also help us understand why religious liberalism tends to signify as white, and why so many people of color have not felt at home within "liberal religion", a problem poignantly described by Sofia Betancourt in her contribution to this forum. Drawing from the activist wells of liberation theology, Betancourt suggests "liberatory" as a term that better conveys the religious commitments of contemporary Unitarian Universalists and signifies the inclusive and justice-oriented faith that most of us seek to embody.

In conclusion, I want to quote the philosopher Rosi Braidotti, whose book The Posthuman develops a closely related critique of philosophical humanism. In order to meaningfully address the ecological and other crises we face, Braidotti argues, we need to move beyond liberal humanist notions of subject formation and individual self-mastery, which deny the relational ways in which we all are formed. These models have undermined accountability to human and other-than-human communities, defeating the goals of social liberation and environmental justice that are my own primary commitments. Braidotti advocates a more relational vision of self-in-community, "critical posthuman subjects" who are constituted by and accountable to their "multiple belongings" (Braidotti 2013). Following Betancourt and Braidotti, then, I would call for Unitarian Universalists to identify themselves not with "religious liberalism" or "liberal religion" but as a relational community of flourishing and liberation for all.

Funding: This research received no external funding.

Conflicts of Interest: The authors declare no conflict of interest.

\section{References}

Braidotti, Rosi. 2013. The Posthuman. Cambridge and Malden: Polity Press, p. 49.

Brown, Wendy. 2015. Undoing the Demos: Neoliberalism's Stealth Revolution. New York: Zone Books.

Comaroff, Jean, and John L. Comaroff, eds. 2001. Millennial Capitalism and the Culture of Neoliberalism. Durham: Duke University Press.

Engel, Jeffrey, ed. 2015. The Four Freedoms: FDR's Legacy of Liberty for the United States and the World. Oxford: Oxford University Press.

Hartman, Saidiya V. 1997. Scenes of Subjection: Terror, Slavery, and Self-Making in Nineteenth-Century America. Oxford and New York: Oxford University Press.

Jordan, Ryan P. 2012. Church, State, and Race: The Discourse of American Religious Liberty, 1750-1900. Lanham: University Press of America.

Lowe, Lisa. 2015. The Intimacies of Four Continents. Durham: Duke University Press Books.

McKanan, Dan. 2011. Prophetic Encounters: Religion and the American Radical Tradition. Boston: Beacon Press.

Mehta, Uday Singh. 1999. Liberalism and Empire: A Study in Nineteenth-Century British Liberal Thought. Chicago: University of Chicago Press.

Patterson, Orlando. 1991. Freedom in the Making of Western Culture. New York: Basic Books, vol. 1.

Rasor, Paul. 2013. Reclaiming Prophetic Witness: Liberal Religion in the Public Square. Boston: Skinner House Books. Wenger, Tisa. 2017. Religious Freedom: The Contested History of an American Ideal. Chapel Hill: The University of North Carolina Press.

(C) 2020 by the authors. Licensee MDPI, Basel, Switzerland. This article is an open access article distributed under the terms and conditions of the Creative Commons Attribution (CC BY) license (http://creativecommons.org/licenses/by/4.0/). 